\title{
Durum wheat quality: II. The relationship of kernel physicochemical composition to semolina quality and end product utilisation
}

Samaan, J

http://hdl.handle.net/10026.1/1438

10.1111/j.1365-2621.2006.01313.x

International Journal of Food Science and Technology

Wiley

All content in PEARL is protected by copyright law. Author manuscripts are made available in accordance with publisher policies. Please cite only the published version using the details provided on the item record or document. In the absence of an open licence (e.g. Creative Commons), permissions for further reuse of content should be sought from the publisher or author. 


\title{
Original article
}

\section{Durum wheat quality: II. The relationship of kernel physicochemical composition to semolina quality and end product utilisation}

\author{
Jihad Samaan, ${ }^{1}$ Ghassan H. El-Khayat, ${ }^{1,2}$ Frank A. Manthey, ${ }^{3}$ Mick P. Fuller ${ }^{1}$ \& Charles S. Brennan ${ }^{1,4 *}$ \\ 1 Applied Food Research Group, University of Plymouth, Newton Abbot, Devon, TQ12 6NQ, UK \\ 2 Food Science Department, Faculty of Agriculture, University of Damascus, Damascus, Syria \\ 3 Department of Plant Sciences, North Dakota State University, Fargo, ND 58105-5728, USA \\ 4 Institute of Food Nutrition and Health, Massey University, Private Bag 11222 Palmerston North, New Zealand
}

(Received 17 August 2005; Accepted in revised form 31 October 2005)

\begin{abstract}
Summary Kernel quality characteristics, semolina milling potential, dough rheology and pasta making properties of kernels from nine fully irrigated Syrian durum wheat genotypes were observed. Protein content of the kernels exerted a significant affect on the physical characteristics hardness and the degree of kernel vitreousness, both of which were highly correlated with superior end-use product. Gluten composition of semolina appeared as significant as overall protein content in determining the optimum end-use product cooking quality (cooking time and pasta texture). The final viscosity of durum flour exhibited positive correlations with semolina recovery, protein content, gluten content, vitreousness, the optimum-cooking time of pasta and pasta firmness. This indicates the relevance of using the rapid visco analyser technique in evaluating the durum wheat and pasta qualities. Dough rheology measurements confirmed that farinograph and extensograph are useful indicators of the cooking properties of pasta. The research also illustrates that although variability between Syrian durum wheat genotypes were observed, their milling and processing parameters were similar to those previously reported for Canadian and American durum wheats, indicating the potential to use these lines in mainstream pasta production.
\end{abstract}

Keywords Gluten, pasta, rapid visco analyser, semolina, vitreous.

\section{Introduction}

The majority of durum wheat (Triticum turgidum var. durum) grown in the Mediterranean countries is milled to form durum wheat semolina. This in turn is used in the manufacture of a multitude of cereal food products, with pasta being the most important in terms of commodity value. The milling requirements of durum wheat are significantly different to those of hard and soft bread wheats (Triticum aestivum). The objective of durum wheat milling is to remove the bran and germ from the endosperm and to coarsely grind the endosperm. In general, the particle size of semolina in the USA is such that the entire product passes through a no. 20 sieve ( $840 \mu \mathrm{m}$ aperture size), with no more than $3 \%$ passing through a no. 100 sieve (149 $\mu \mathrm{m}$ aperture size). In contrast, the particle size of bread wheat flour is normally within the range of $75-150 \mu \mathrm{m}$.

Durum wheat kernels tend to be harder than bread wheat kernels (Miller et al., 1982). This is assumed to be

*Correspondent: Fax: + 64 (0)6 3505657 ;

e-mail: c.s.brennan@massey.ac.nz due to the absence of the starch granule puroindoline protein on the surface of the starch granules (Greenwell \& Schofield, 1986). Therefore, in order to crack the durum wheat kernel and produce both semolina and durum wheat flour, a high force needs to be applied during milling (Mousa et al., 1983). Durum wheat can be tempered prior to milling in order increase the friability of the endosperm and to reduce the energy required for milling. This tempering is typically used to increase the grain moisture to $17-17.5 \%$ moisture in stages over 16-24-h period.

The milling quality of durum wheat is often assessed by the potential extraction rate of the kernels (extraction rate representing the proportion of wheat that is milled into semolina). A high semolina extraction rate reduces the amount of the smaller-sized durum wheat flour and optimises the kernel utilisation for pasta production (Troccoli et al., 2000).

Extensive research has been conducted in order to determine the semolina characteristics required to make high quality pasta (Dexter \& Matsuo, 1980; Dexter et al., 1983, 1987; D'Egidio et al., 1990; Dexter et al., 1994; Kovacs et al., 1995; Ames et al., 1999; Manthey \& 
Schorno, 2002). The majority of these characteristics are related to dough development, with the protein content and quality of the semolina being closely linked to the elasticity, extensibility and resistance to overcooking of pasta, in a similar way to which gluten has been related to bread dough viscoelastic properties (MacRitchie, 1984; Shewry \& Miflin, 1985; Payne, 1987; Wrigley \& Bietz, 1988; Gupta et al., 1989; Khan et al., 1990; Gupta et al., 1992; Weegels et al., 1996). Additionally, ash content has been linked to semolina colour where it is used to assess the cleanliness of semolina (Pomeranz, 1987), and hence the appearance of the finished pasta (Troccoli et al., 2000).

Cubadda (1988) investigated the relationship of several semolina characteristics to pasta quality. Assessments were based firstly on the factors that affect dough development and some of the quality aspects of the end-use product, and secondly on factors affecting the cooking quality of pasta. The work illustrated that the particle size distribution of semolina affected dough development by regulating hydration during the mixing stage. Improper hydration is detrimental to dough development so that dough strength tends to decline with increased hydration, partly because of the lack of gluten network formation (Cubadda, 1989).

Dexter \& Matsuo (1977) investigated the influence of protein on some of durum wheat quality aspects for two Canadian durum wheat cultivars and found that an increase in protein content was associated with an increase in pigment content and improvement in cooking quality of resulting pasta together with improved tolerance to overcooking. Further work by the same authors investigated thirty lines of durum wheat differing in spaghetti cooking quality (Dexter \& Matsuo, 1980). They found that gluten strength had a strong influence on farinograph properties, which, in turn, could be related to improve the pasta cooking quality.

The aim of this work was to extend these previous research findings by studying the aspects of the milling and processing potential of nine Syrian durum wheat genotypes grown under the same environmental conditions, and determining the specific correlations between the physicochemical characteristics of durum wheat kernels, semolina characteristics and pasta quality.

\section{Materials and methods}

Nine Syrian spring durum wheat genotypes, SHAM-1, SHAM-3, SHAM-5, BOHOUTH-5, BOHOUTH-7, DOUMA-1105, DOUMA-18861, DOUMA-26827 and DOUMA-29019 were selected. These are from lines recommended for irrigated lands. The first five genotypes are currently in use as on farm cultivars, while the DOUMA genotypes are still in a process of accreditation. The samples were obtained from the Ministry of Agriculture Research Station at Raqqa (Northeast) of
Syria, which is one of Syria's main durum wheatgrowing provinces. All genotypes were grown at the same location and under the same agroecological conditions in the crop year 2002 as described in our previous paper (El-Khayat et al., 2006).

Grain was cleaned using a Carter-Day dockage tester (Simon-Carter Company, Minneapolis, MN, USA) that was configured with a number 25 riddle, and two number 2 sieves. Grain was scoured using a cyclone grain cleaner (Foster Manufacturers, Wichita, KS, USA) and tempered to $17.5 \%$ moisture. Tempered grain was milled into semolina using a Bühler experimental mill fitted with two Miag laboratory scale purifiers (Bühler-Miag, Minneapolis, MN, USA). Semolina extraction was expressed on a total product basis.

\section{Physicochemical analysis of wheat kernels}

Kernel starch content and semolina moisture, protein, gluten content, falling number, and ash were analysed for: kernel vitreouseness, hardness, test weight, 1000 kernel weight, moisture, protein, gluten and falling number (as reported in our previous paper, El-Khayat et al., 2006). Amylose content of starch extracted from whole kernels was determined using the Megazyme amylose and amylopectin assay kit (Megazyme International, Wicklow, Ireland). The pasting characteristics of ground durum wheat kernels were investigated using the RVA (rapid visco analyser; Newport Scientific, Warriewood, Australia), adopting the methodology of ElKhayat et al. (2003).

Semolina particle size distribution was conducted using the US standard sieves no. $30(549 \mu \mathrm{m})$, no. 40 $(420 \mu \mathrm{m})$, no. $60(250 \mu \mathrm{m})$, no. $80(178 \mu \mathrm{m})$ and no. 100 $(149 \mu \mathrm{m})$, which were connected to a Rotap sieve shaker. A $100 \mathrm{~g}$ of semolina was shaken for $5 \mathrm{~min}$, and the separated fractions on the top of each sieve were weighed and expressed as a per cent of the whole sample.

\section{Pasta dough characteristics}

Extensograph analysis was determined according to the approved AACC method 54-10 (American Association of Cereal Chemists, 2000), measurements recorded were extensibility, resistance to extension, energy and proportional number. Farinograph analysis of semolina samples was determined according to the approved AACC method 54-21 (American Association of Cereal Chemists, 2000) to evaluate the water absorption of the samples.

\section{Pasta production}

Spaghetti samples were processed according to the procedure described by Walsh et al. (1971) and in the 
approved AACC method 66-41 (American Association of Cereal Chemists, 2000). Semolina (1 kg) was mixed with water to reach $32 \%$ absorption. The hydrated semolina was mixed at high speed in a Hobart mixer (Hobart Corporation, Troy, OH, USA) for $4 \mathrm{~min}$, placed in a mixing chamber under vacuum, and extruded as spaghetti through an 84-strand Teflon-coated die using a DeMaCo semi-commercial laboratory extruder (DeFrancisci Machine Corp., Melbourne, FL, USA). The extruder was operated under the following conditions: extrusion temperature of $45^{\circ} \mathrm{C}$, mixing chamber vacuum with $46 \mathrm{~cm}$ of $\mathrm{Hg}$, and auger extrusion speed of 25 r.p.m.

Extruded spaghetti samples were dried at high temperature $73{ }^{\circ} \mathrm{C}$ for $12 \mathrm{~h}$ at a relative humidity of $83 \%$.

\section{Pasta quality analysis}

Pasta cooked weight was determined according to the approved AACC method 66-50 (American Association of Cereal Chemists, 2000), with some modifications described by Dick et al. (1974), where $10 \mathrm{~g}$ of dry pasta, broken into approximately $5-\mathrm{cm}$ length, and boiled in $300 \mathrm{~mL}$ of distilled water. Each pasta sample was cooked to its optimal cooking time (defined as the time required for the white core in the centre of the pasta strand to disappear). Optimum-cooking time was assessed by removing a strand from the cooking water every $30 \mathrm{~s}$ and cut between two plexiglass plates. Subsequently, the cooked pasta was rinsed with distilled water $25^{\circ} \mathrm{C}$ and drained for $2 \mathrm{~min}$, weighed, and the final weight reported in gram.

Cooking loss was conducted by the AACC approved method 66-50, where the cooking water and rinse water were dried in an air oven at $110{ }^{\circ} \mathrm{C}$, and the residue was weighed and reported as a percentage of the total dry sample weight (Dick et al., 1974).

Pasta firmness was determined as of Tudorica et al. (2002) using a Stable Microsystems TAXTII machine (Stable Microsystems, Reading, UK) according to the approved AACC method 66-50 (American Association of Cereal Chemists, 2000). The mechanical strength of dried pasta was determined by placing ten strands from each sample (10-cm long) on the heavy duty stage of the Texture Analyser, and the samples cut with a craft knife.

\section{Statistics}

All measured characteristics were conducted in triplicate and expressed as means, apart from farinograph analysis which was performed in duplicate. Correlation coefficients were run between the different variables using the MICROSOFT EXCEL. Analysis of variance (ANOVA) was performed using MINITAB 1332 software package (Minitab Inc., State College, PA, USA).

\section{Results and discussion}

Table 1 details the extraction rates and particle size analysis of the semolina from the nine Syrian durum wheat lines. Extraction rates for semolina varied between genotypes from 62.7\% (Douma 1105) to 65.5\% (Bohouth 5 and 7). Douma 1105, 26827 and Sham 3 all yielded significantly lower extraction rates than the Bohouth samples. However, the extraction rates observed are within the expected ranges for hard durum wheat material (60-68\%).

Although the semolina extraction rate is important from a commercial basis, research conducted by Dexter \& Matsuo (1978a) has indicated that the extraction rate of semolina may not exhibit a significant effect on spaghetti cooking quality. Conversely, semolina particle size distribution has an important role in pasta making because of its effect on the hydration rate (Posner \& Hibbs, 1997). Grant et al. (1993) demonstrated that as semolina PSI decreased, water absorption increased, and the firmness of the resulting spaghetti decreased. Table 1 illustrates that the amount of material with a particle size $>250 \mu \mathrm{m}$ did not significantly vary between

Table 1 Semolina extraction rate and particle size distribution of durum semolina

\begin{tabular}{llllllll}
\hline Cultivars & Semolina extraction \% & \% No. 30** & \% No. 40** & \% No. 60** & \% No. 80** & \% No. 100** & \% Pass no. 100** \\
\hline Sham-1 & $64.2^{\mathrm{a}, \mathrm{b}}$ & 0.63 & 11.50 & 47.30 & 27.20 & 4.20 & 9.10 \\
Sham-3 & $62.9^{\mathrm{b}}$ & 0.60 & 11.30 & 48.30 & 26.70 & 4.30 & 8.80 \\
Sham-5 & $65.0^{\mathrm{a}}$ & 0.56 & 10.70 & 47.90 & 27.50 & 4.50 & 9.00 \\
Bohouth-5 & $65.5^{\mathrm{a}}$ & 0.52 & 10.40 & 48.70 & 27.20 & 4.40 & 8.60 \\
Bohouth-7 & $65.5^{\mathrm{a}}$ & 0.50 & 10.70 & 48.40 & 27.50 & 4.40 & 8.20 \\
Douma-1105 & $62.7^{\mathrm{b}}$ & 0.60 & 9.80 & 48.00 & 27.40 & 4.60 & 9.20 \\
Douma-18861 & $64.7^{\mathrm{a}}$ & 0.50 & 10.60 & 47.10 & 27.50 & 4.70 & 9.00 \\
Douma-26827 & $62.9^{\mathrm{b}}$ & 0.50 & 10.70 & 47.40 & 27.40 & 4.70 & 9.00 \\
Douma-29019 & $64.0^{\mathrm{c}}$ & 0.60 & 10.50 & 46.60 & 27.50 & 4.60 & 9.70 \\
\hline
\end{tabular}

${ }^{a}$ Means values in the same column, followed by a different letter are significantly different $(P<0.05)$.

**No significant difference observed between cultivars in particle size distribution. 
lines (60.2\% Sham $-1 ; 57.7 \%$ Douma 29019). All of the lines demonstrated a predominant amount of material retained on no. 60 sieve (between 250 and $420 \mu \mathrm{m}$ ), which is the preferential level for pasta semolina.

Table 2 details some of the physical characteristics of tested durum wheat genotypes and the chemical compositions of the subsequent semolina used in the production of pasta. These results are reported as example of the data used in the calculation of correlations reported in Table 3.

Our previous paper has discussed some of the variations observed between lines in their kernel characteristics (El-Khayat et al., 2006). Semolina moisture ranged between $13.33 \%$ and $13.80 \%$, whereas ash content ranged from $0.64 \%$ to $0.75 \%$. Between lines, variations were not significant. These values are similar to those reported for semolina from durum wheat grown in Canada and the US. The protein content of the semolinas (on a $14 \%$ moisture level) was relatively low with the semolina of Douma 18861 exhibiting the higher protein levels than the rest of the samples, and the semolinas of Sham 3 and Douma 26827 exhibiting the lowest protein contents. A similar pattern was observed for both wet and dry gluten.

Table 3 illustrates correlations between the physicochemical properties of the durum wheat kernels and the milling potentials. The rate of semolina extraction showed a positive correlation to semolina protein content $(r=0.67)$. A positive correlation was also observed between semolina extraction and kernel hardness $(r=0.76)$, and degree of vitreousness $(r=0.57)$. Generally, protein content of a semolina is regarded as being linked to the level of semolina extraction as protein content increases from the centre of the endosperm outward towards the aleurone and bran layer. Thus, as milling extraction increases, more endosperm

Table 2 Some physiochemical characteristics of durum wheat kernels, and subsequent semolina, used for pasta production

\begin{tabular}{|c|c|c|c|c|c|c|c|c|c|c|c|c|}
\hline \multirow[b]{2}{*}{ Cultivars } & \multicolumn{6}{|c|}{ Kernel characteristics } & \multicolumn{6}{|c|}{ Semolina characteristics } \\
\hline & $\begin{array}{l}\text { Hardness } \\
\text { Av. }\end{array}$ & $\begin{array}{l}\text { Vitreousness } \\
\%\end{array}$ & $\begin{array}{l}1000 \text { kernal } \\
\text { weight }(\mathrm{g})\end{array}$ & $\begin{array}{l}\text { Test } \\
\text { weight } \\
\text { in } \mathbf{k g ~} \mathbf{h l}^{-1}\end{array}$ & $\begin{array}{l}\text { Amylose } \\
\%\end{array}$ & $\begin{array}{l}\text { Starch \% } \\
\text { on dry } \\
\text { base }\end{array}$ & $\begin{array}{l}\text { Moisture } \\
\%\end{array}$ & $\begin{array}{l}\text { Ash } \% \\
\text { on } 14 \% \\
\text { moist. }\end{array}$ & $\begin{array}{l}\text { Protein } \% \\
\text { on } 14 \% \\
\text { moist. }\end{array}$ & $\begin{array}{l}\text { Wet } \\
\text { gluten } \\
\text { (g) }\end{array}$ & $\begin{array}{l}\text { Dry } \\
\text { gluten } \\
\text { (g) }\end{array}$ & $\begin{array}{l}\text { Falling } \\
\text { no. } \\
\text { second }\end{array}$ \\
\hline Sham-1 & $89.1^{\mathrm{a}}$ & $71.33^{a}$ & $50.31^{a}$ & $84.90^{a}$ & $28.3^{a}$ & $64.43^{\mathrm{a}}$ & $13.80^{\mathrm{a}}$ & $0.69^{\mathrm{a}}$ & $10.22^{\mathrm{a}}$ & $26.48^{a}$ & $9.88^{\mathrm{a}}$ & $433^{a}$ \\
\hline Sham-3 & $86.7^{a}$ & $52.70^{\mathrm{b}}$ & $55.54^{a}$ & $83.10^{\mathrm{a}}$ & $27.6^{\mathrm{a}}$ & $64.29^{a}$ & $13.54^{\mathrm{a}}$ & $0.75^{\mathrm{a}}$ & $9.31^{b}$ & $25.00^{a, b}$ & $8.96^{b}$ & $528^{b}$ \\
\hline Sham-5 & $95.7^{\mathrm{b}}$ & $60.43^{\mathrm{c}}$ & $50.35^{\mathrm{a}}$ & $84.90^{\mathrm{a}}$ & $27.8^{\mathrm{a}}$ & $65.01^{\mathrm{a}}$ & $13.72^{\mathrm{a}}$ & $0.74^{\mathrm{a}}$ & $10.34^{a}$ & $27.49^{a, c}$ & $10.30^{\mathrm{a}}$ & $502^{\mathrm{b}}$ \\
\hline Bohouth-5 & $94.3^{a, b}$ & $63.07^{\mathrm{c}}$ & $55.12^{a}$ & $84.10^{\mathrm{a}}$ & $29.0^{\mathrm{a}}$ & $66.24^{\mathrm{b}}$ & $13.56^{\mathrm{a}}$ & $0.67^{\mathrm{a}}$ & $10.08^{a, b}$ & $24.41^{\mathrm{b}}$ & $9.20^{\mathrm{b}}$ & $505^{\mathrm{b}}$ \\
\hline Bohouth-7 & $100.9^{b}$ & $85.73^{d}$ & $49.62^{a}$ & $85.50^{\mathrm{a}}$ & $29.8^{\mathrm{a}}$ & $66.82^{\mathrm{b}}$ & $13.52^{a}$ & $0.69^{a}$ & $10.24^{a}$ & $27.32^{a, c}$ & $9.31^{b}$ & $597^{\mathrm{c}}$ \\
\hline Douma-1105 & $91.5^{a, b}$ & $63.33^{c}$ & $50.71^{a}$ & $84.15^{a}$ & $30.4^{\mathrm{a}}$ & $64.39^{a}$ & $13.39^{a}$ & $0.66^{\mathrm{a}}$ & $9.97^{a, b}$ & $26.13^{a}$ & $8.96^{b}$ & $472^{d}$ \\
\hline Douma-18861 & $96.1^{\mathrm{b}}$ & $93.63^{\mathrm{e}}$ & $50.81^{a}$ & $83.70^{a}$ & $28.7^{\mathrm{a}}$ & $64.42^{a}$ & $13.41^{\mathrm{a}}$ & $0.65^{\mathrm{a}}$ & 10.85 & $29.37^{d}$ & $10.61^{a}$ & $524^{b}$ \\
\hline Douma-26827 & $90.6^{a, b}$ & $50.43^{b}$ & $42.53^{b}$ & $85.50^{a}$ & $28.0^{\mathrm{a}}$ & $68.24^{\mathrm{c}}$ & $13.55^{a}$ & $0.71^{\mathrm{a}}$ & $9.48^{b}$ & $25.69^{b}$ & $9.14^{\mathrm{a}}$ & $485^{d}$ \\
\hline Douma-29019 & $89.3^{a}$ & $69.40^{\mathrm{a}}$ & $50.41^{a}$ & $85.90^{a}$ & $27.8^{\mathrm{a}}$ & $68.28^{c}$ & $13.33^{a}$ & $0.64^{a}$ & $10.10^{a}$ & $28.14^{\mathrm{c}, \mathrm{d}}$ & $9.68^{a, b}$ & $501^{b}$ \\
\hline
\end{tabular}

${ }^{a}$ Means values in the same column followed by a different letter are significantly different $(P<0.05)$.

Table 3 Correlations between the physicochemical properties of the durum wheat kernels and the milling potentials

\begin{tabular}{|c|c|c|c|c|c|c|c|c|c|c|c|c|}
\hline & $\begin{array}{l}\text { Semolina } \\
\text { extraction }\end{array}$ & $\begin{array}{l}\text { Falling } \\
\text { no. }\end{array}$ & Protein & $\begin{array}{l}\text { Wet } \\
\text { gluten }\end{array}$ & $\begin{array}{l}\text { Dry } \\
\text { gluten }\end{array}$ & Starch & Hardness & Vitreousness & $\begin{array}{l}1000 \text { kernel } \\
\text { weight }\end{array}$ & $\begin{array}{l}\text { Test } \\
\text { weight }\end{array}$ & Moisture & Ash \\
\hline Amylose & 0.12 & 0.20 & 0.26 & -0.03 & -0.29 & -0.17 & $0.50^{* *}$ & 0.39 & 0.04 & -0.06 & -0.30 & $-0.41^{*}$ \\
\hline Semolina extraction & & $0.43^{*}$ & $0.67 * * *$ & 0.28 & $0.47^{*}$ & 0.07 & $0.76 * * *$ & $0.57^{* *}$ & 0.25 & 0.18 & 0.24 & -0.17 \\
\hline Falling no. & & & 0.10 & 0.21 & -0.07 & 0.20 & $0.65^{* *}$ & $0.40 *$ & 0.16 & 0.00 & -0.33 & 0.08 \\
\hline Protein & & & & $0.76^{* * *}$ & $0.82 * * *$ & -0.23 & $0.63^{* *}$ & $0.84^{* * *}$ & 0.07 & 0.08 & -0.03 & $-0.56^{* *}$ \\
\hline Wet gluten & & & & & $0.79 * * *$ & 0.00 & 0.39 & $0.74 * * *$ & -0.24 & 0.28 & -0.29 & $-0.46^{*}$ \\
\hline Dry gluten & & & & & & -0.23 & 0.32 & $0.58 * *$ & -0.06 & 0.06 & 0.19 & -0.22 \\
\hline Starch & & & & & & & 0.07 & -0.15 & $-0.54^{* *}$ & $0.78^{* * *}$ & -0.31 & -0.22 \\
\hline Hardness & & & & & & & & $0.63 * *$ & -0.09 & 0.20 & -0.02 & -0.16 \\
\hline Vitreousness & & & & & & & & & 0.08 & 0.05 & -0.23 & -0.58 \\
\hline 1000 kernel weight & & & & & & & & & & $-0.66 * * *$ & -0.02 & 0.01 \\
\hline Test weight & & & & & & & & & & & 0.02 & -0.21 \\
\hline Moisture & & & & & & & & & & & & $0.63^{* *}$ \\
\hline
\end{tabular}

$*, * * * *$ Correlation significantly different at the $0.05,0.01$ and 0.001 level of probability, respectively. 
near the bran and aleurone layers is removed, resulting in increased semolina protein content. The semolina yields for most of the lines investigated were on the lower side of acceptability, this would indicate a removal of starchy endosperm region around the bran layer, and explain the low semolina protein levels within our samples. The semolina protein content of the lines followed similar correlation patterns to that previously recorded in our previous paper concentrating on their kernel proteins (El-Khayat et al., 2006), which showed positive correlations to wet and dry gluten content, whilst negative correlations to ash and starch content. Table 3 illustrates that both kernel hardnesses, and also the degree of vitreousness within kernels, are correlated to the amount of protein in the semolina recovered after milling ( $r=0.63$ and 0.84 , respectively). This observation is consistent with previous research indicating that vitreous kernels are harder, and of higher protein content, than starchy kernels (Stenvert \& Kingswood, 1977; Dexter et al., 1989; El-Khayat et al., 2003). As such, the results clearly illustrate the importance of protein content on kernel hardness, the degree of kernel vitreousness and milling potential.

Table 4 illustrates some of the quality characteristics of the cooked pasta obtained from the durum wheat samples. Optimum-cooking time ranged from 9 min for Sham-3 and Douma-26827 to $10.5 \mathrm{~min}$ for Douma18861. Actual cooked weight showed no significant difference among the cooked pasta samples and ranged between 29.56 and $30.50 \mathrm{~g}$. On the other hand, cooking loss residue and cooked firmness demonstrated significant variations among spaghetti made from the different lines. Cooking loss ranged from $5.9 \%$ for Bohouth-5 to $7.33 \%$ for Douma- 1105 .

When the tested pasta samples were overcooked 6 min, increases in cooked weight and cooking loss associated with a decrease in firmness were observed (Table 4). As would be expected, all the tested pasta samples exhibited significant increases in cooked weight when overcooked by $6 \mathrm{~min}$, compared with the cooked weight in optimum time.

The physicochemical composition of the kernel has an important role with regard to processing and cooking quality of pasta from durum semolina. Table 5 illustrates the correlations between some of these physicochemical properties and processing qualities.

Numerous investigations have been detected to find the relationship between test weight and milling potential (Mangels, 1960; Shuey, 1960; Johnson \& Hartsing, 1963; Barmore \& Bequette, 1965; Shuey \& Gilles, 1972; Watson et al., 1977a,b; Matsuo \& Dexter, 1980; Matsuo et al., 1982; Hook, 1984; Dexter et al., 1987). Of these, Dexter et al. (1987) demonstrated a highly significant correlation among test weight, milling characteristics and pasta quality, where a linear decrease of $0.7 \%$ in semolina yield was associated with a $1-\mathrm{kg}$ decrease in test weight. However, Hook (1984), when reviewing the relationship between test weight and milling potential, suggested that there was no general agreement among the researchers with regard to the use of test weight as a predicting index for milling potential. This supports our finding, where the correlation between test weight and milling extraction was poor $(r=0.18)$.

Amylose content of the durum wheat semolina showed positive correlations to farinograph water absorbance, optimum-cooking time and cooking loss of the pasta, whilst being negatively correlated to peak viscosity (Table 5). These results are in general agreement with previous research demonstrating that lower amylose is associated with higher peak viscosity, and variations in water absorption (Zeng et al., 1997; Jane et al., 1999). Similarly, Sharma et al. (2002), when

Table 4 Cooking characteristics of pasta produced from a range of Syrian durum wheat cultivar

\begin{tabular}{|c|c|c|c|c|c|c|c|c|c|c|}
\hline \multirow[b]{2}{*}{ Cultivars } & \multirow{2}{*}{$\begin{array}{l}\text { Optimum- } \\
\text { cooking } \\
\text { time in } \\
\text { minute }\end{array}$} & \multirow[b]{2}{*}{$\begin{array}{l}\text { Actual } \\
\text { cooked } \\
\text { wt. (g) }\end{array}$} & \multirow[b]{2}{*}{$\begin{array}{l}\text { Residue } \\
\text { (g) }\end{array}$} & \multirow[b]{2}{*}{$\begin{array}{l}\text { Firmness } \\
\left(\mathrm{g} \mathrm{cm}^{-1}\right)\end{array}$} & \multicolumn{3}{|c|}{ Optimum time plus six min. } & \multirow{2}{*}{$\begin{array}{l}\text { Breaking } \\
\text { force of } \\
\text { dried } \\
\text { pasta }(g)\end{array}$} & \multirow[b]{2}{*}{$\begin{array}{l}\text { Number of } \\
\text { checks of } \\
\text { dried pasta }\end{array}$} & \multirow[b]{2}{*}{$\begin{array}{l}\text { Colour } \\
\text { score of } \\
\text { dried pasta }\end{array}$} \\
\hline & & & & & $\begin{array}{l}\text { Cooked } \\
\text { weight } \\
\text { (g) }\end{array}$ & $\begin{array}{l}\text { Residue } \\
\text { (g) }\end{array}$ & $\begin{array}{l}\text { Firmness } \\
\left(\mathrm{g} \mathrm{cm}^{-1}\right)\end{array}$ & & & \\
\hline Sham-1 & $9.50^{\mathrm{a}}$ & $30.22^{\mathrm{a}}$ & $6.10^{\mathrm{a}}$ & $3.80^{\mathrm{a}}$ & $37.06^{\mathrm{a}}$ & $7.93^{\mathrm{a}}$ & $3.10^{\mathrm{a}}$ & $102.1^{\mathrm{a}}$ & $105^{\mathrm{a}}$ & $8.5^{\mathrm{a}}$ \\
\hline Sham-3 & $9.00^{\mathrm{b}}$ & $30.11^{\mathrm{a}}$ & $6.23^{a, b}$ & $3.60^{\mathrm{a}}$ & $37.29^{a}$ & $7.87^{\mathrm{a}}$ & $2.90^{\mathrm{a}}$ & $94.3^{\mathrm{b}}$ & $55^{\mathrm{b}}$ & $8.0^{\mathrm{b}}$ \\
\hline Sham-5 & $9.50^{\mathrm{a}}$ & $30.27^{\mathrm{a}}$ & $6.07^{\mathrm{a}}$ & $4.50^{\mathrm{b}}$ & $36.50^{\mathrm{a}}$ & $6.77^{\mathrm{a}}$ & $3.40^{\mathrm{a}, \mathrm{b}}$ & $99.5^{a, c}$ & $77^{\mathrm{c}}$ & $7.0^{\mathrm{C}}$ \\
\hline Bohouth-5 & $9.50^{\mathrm{a}}$ & $30.50^{\mathrm{a}}$ & $5.90^{\mathrm{a}}$ & $3.70^{\mathrm{a}}$ & $35.87^{\mathrm{a}}$ & $7.60^{\mathrm{a}}$ & $3.10^{\mathrm{a}}$ & $97.4^{\mathrm{b}, \mathrm{c}}$ & $67^{b, c}$ & $7.0^{\mathrm{C}}$ \\
\hline Bohouth-7 & $9.50^{\mathrm{a}}$ & $29.56^{\mathrm{a}}$ & $6.50^{\mathrm{b}}$ & $4.40^{\mathrm{b}}$ & $34.93^{\mathrm{a}}$ & $7.90^{\mathrm{a}}$ & $3.70^{\mathrm{b}, \mathrm{c}}$ & $98.6^{\mathrm{C}}$ & $53^{b}$ & $8.5^{\mathrm{a}}$ \\
\hline Douma-1105 & $10.00^{c}$ & $30.27^{\mathrm{a}}$ & $7.33^{\mathrm{c}}$ & $3.80^{\mathrm{a}}$ & $35.13^{\mathrm{a}}$ & $8.33^{\mathrm{a}}$ & $3.20^{\mathrm{a}}$ & $100.6^{c}$ & $37^{\mathrm{b}}$ & $8.0^{\mathrm{b}}$ \\
\hline Douma-18861 & $10.50^{\mathrm{c}}$ & $29.55^{a}$ & $6.13^{a, b}$ & $5.50^{\mathrm{c}}$ & $34.67^{\mathrm{a}}$ & $7.33^{\mathrm{a}}$ & $4.10^{\mathrm{C}}$ & $101.5^{\mathrm{a}, \mathrm{c}}$ & $53^{b}$ & $9.0^{d}$ \\
\hline Douma-26827 & $9.00^{\mathrm{b}}$ & $29.67^{a}$ & $6.72^{\mathrm{b}}$ & $4.20^{\mathrm{a}, \mathrm{b}}$ & $35.46^{\mathrm{a}}$ & $7.77^{\mathrm{a}}$ & $3.20^{\mathrm{a}}$ & $104.3^{a, c}$ & $73^{c}$ & $8.5^{\mathrm{a}}$ \\
\hline Douma-29019 & $9.50^{\mathrm{a}}$ & $29.67^{\mathrm{a}}$ & $6.20^{\mathrm{a}}$ & $4.50^{\mathrm{b}}$ & $35.38^{\mathrm{a}}$ & $7.70^{\mathrm{a}}$ & $3.60^{a, b}$ & $100.2^{\mathrm{c}}$ & $41^{\mathrm{b}}$ & $8.5^{\mathrm{a}}$ \\
\hline
\end{tabular}

${ }^{a}$ Means values in the same column, followed by a different letter are significantly different $(P<0.05)$. 
Table 5 Correlations between dough rheology and pasta quality

\begin{tabular}{|c|c|c|c|c|c|c|c|c|c|}
\hline & Extensibility & Resistance & $\begin{array}{l}\text { Water } \\
\text { absorption }\end{array}$ & $\begin{array}{l}\text { Optimum-cooking } \\
\text { time }\end{array}$ & Residue & $\begin{array}{l}\text { Pasta } \\
\text { firmness }\end{array}$ & $\begin{array}{l}\text { Spaghetti } \\
\text { hardness }\end{array}$ & $\begin{array}{l}\text { Peak } \\
\text { viscosity }\end{array}$ & $\begin{array}{l}\text { Final } \\
\text { viscosity }\end{array}$ \\
\hline Amylose & -0.24 & -0.11 & $0.82 * * *$ & $0.50 *$ & $0.60 * *$ & -0.07 & 0.06 & $-0.82 * * *$ & -0.07 \\
\hline Semolina extraction & -0.30 & -0.26 & $0.45^{*}$ & 0.26 & $-0.63^{* *}$ & 0.34 & -0.16 & 0.24 & $0.53^{*}$ \\
\hline Falling no. & -0.25 & $0.47^{*}$ & 0.18 & 0.01 & -0.09 & 0.32 & $-0.47^{*}$ & 0.07 & 0.31 \\
\hline Protein & 0.28 & $-0.63^{* *}$ & $0.42 *$ & $0.83 * * *$ & -0.31 & $0.72 * * *$ & 0.27 & 0.12 & $0.62 * *$ \\
\hline Wet gluten & $0.65^{* *}$ & -0.31 & -0.08 & $0.64 * *$ & -0.10 & $0.90 * * *$ & 0.37 & 0.21 & $0.51 *$ \\
\hline Dry gluten & $0.52 *$ & $-0.55^{*}$ & -0.08 & $0.57 * *$ & $-0.52 *$ & $0.78 * * *$ & 0.32 & $0.52 *$ & $0.57 * *$ \\
\hline Starch & -0.18 & 0.04 & $-0.41^{*}$ & $-0.41^{*}$ & 0.03 & 0.09 & 0.30 & 0.05 & 0.13 \\
\hline Hardness & -0.16 & -0.15 & $0.56^{*}$ & $0.42 *$ & -0.06 & $0.51^{*}$ & 0.04 & -0.16 & $0.40 *$ \\
\hline Vitreousness & 0.06 & -0.32 & 0.36 & $0.75^{* * *}$ & -0.18 & $0.69 * * *$ & 0.14 & 0.04 & $0.68 * *$ \\
\hline 1000 kernal weight & -0.19 & 0.16 & $0.44^{*}$ & 0.13 & $-0.42 *$ & -0.29 & $-0.85^{* * *}$ & 0.18 & 0.04 \\
\hline Test weight & 0.10 & -0.03 & -0.20 & -0.24 & 0.08 & 0.16 & $0.54^{*}$ & -0.18 & -0.07 \\
\hline Moisture & -0.20 & 0.04 & 0.03 & -0.37 & -0.39 & -0.33 & 0.04 & 0.13 & -0.28 \\
\hline Ash & -0.12 & $0.62 * *$ & -0.22 & $-0.68 * *$ & -0.10 & $-0.41^{*}$ & -0.35 & 0.14 & $-0.52 *$ \\
\hline Extensibility & & -0.14 & -0.23 & 0.36 & 0.18 & $0.47^{*}$ & 0.27 & 0.08 & -0.13 \\
\hline Resistance & & & -0.11 & $-0.64 * *$ & 0.17 & $-0.43^{*}$ & $-0.59 *$ & -0.15 & $-0.54^{*}$ \\
\hline Water absorption & & & & $0.47^{*}$ & 0.18 & -0.16 & -0.27 & $-0.60 * *$ & -0.11 \\
\hline Optimum cooking & & & & & 0.09 & $0.63^{* *}$ & 0.24 & -0.11 & $0.51^{*}$ \\
\hline Residue & & & & & & -0.18 & 0.30 & $-0.83^{* * *}$ & $-0.51 *$ \\
\hline Pasta firmness & & & & & & & 0.38 & 0.38 & $0.73^{* * *}$ \\
\hline Spaghetti hardness & & & & & & & & -0.15 & 0.15 \\
\hline Peak viscosity & & & & & & & & & $0.58 *$ \\
\hline
\end{tabular}

$* * * * * *$ Correlation significantly different at the $0.05,0.01$ and 0.001 level of probability, respectively.

investigating the relationship of starch and protein content in durum wheat pasta, found a positive correlation to the amount of amylose and the cooking loss $(r=0.62)$ and a negative correlation with peak viscosity $(r=-0.69)$. It is interesting to note that although amylose content affected the peak viscosity of the semolina and also the cooking loss of the pasta, no significant correlation was observed between amylose content and the firmness of the pasta. Additionally, starch content of the semolina did not appear to affect the texture of the pasta produced significantly.

Falling number values of the durum wheat semolina were positively correlated to dough resistance and cooked spaghetti firmness $(r=0.47$ and $r=0.32$, respectively). Matsuo et al. (1982) and Grant et al. (1993) indicated that low falling number values (associated with high $\alpha$-amylase activities because of field sprouting) tended to increase the amount of residue in spaghetti cooking water, and reduced the firmness of spaghetti. This causal relationship may help explain the correlations observed within the Syrian genotypes examined.

Increased protein content of the semolina was linked to increased pasta firmness and a reduction in cooking loss. Work conducted by Grzybowski \& Donnelly (1979) also illustrated that spaghetti cooking loss and firmness were correlated with protein content and gluten strength. This is likely to be associated with the increase observed in optimum-cooking time of pasta made from high protein semolina (Table 5). Both wet and dry gluten content were positively correlated to optimum-cooking time ( $r=0.64$ and 0.57 respectively), with wet gluten content of the pasta being highly correlated to cooked spaghetti firmness $(r=0.90)$. The relationship between protein (gluten) content and pasta textural and cooking properties is associated with the ability of the protein within the pasta to form a tenacious dough structure during mixing, and a firm visco-elastic matrix on cooking. This can be observed in the positive correlations between both wet and dry gluten contents and extensibility of the doughs produced in the extensograph, and the negative correlations of protein content and gluten content to dough resistance to extension.

The importance of protein in dough and pasta quality has been studied extensively (Matsuo et al., 1972; Dexter \& Matsuo, 1977; Grzybowski \& Donnelly, 1979; Dexter \& Matsuo, 1980; Autran \& Galterio, 1989; D’Egidio et al., 1990; Novaro et al., 1993; Sharma et al., 2002; Edwards et al., 2003). Both protein content and gluten composition have been linked to the viscoelastic nature of pasta (Dexter \& Matsuo, 1978b, 1980; Kovacs et al., 1995; Edwards et al., 2003). Research by Kovacs et al. (1995) demonstrated that the mixograph mixing characteristics of durum wheat semolina could be correlated to the viscoelastic nature of cooked pasta, and that these parameters could be correlated to the gluten content (wet and dry) of the semolina rather than 
the viscoelastic behaviour of the semolina doughs. More recently, genetical analyses have revealed the importance of $G l u-A$ and $G l u-B$ loci on protein content and gluten strength of durum wheats (Martinez et al., 2004). Our results support these observations that the gluten composition of the semolina is of more importance than overall protein content. However, it must be emphasised that the protein level of the semolina samples reported in this paper was relatively low. As such, one could speculate that when protein content of the semolina is low the importance of gluten strength (composition) becomes much more important. Further analysis is required to determine the basis behind these observations.

Of the other physicochemical characteristics studied, kernel hardness was observed to be positively correlated to dough water absorbance $(r=0.56)$, pasta optimumcooking time $(r=0.42)$, and pasta firmness $(r=0.51)$. Similarly, the degree of vitreousness was correlated to optimum-cooking time $(r=0.75)$ and pasta firmness $(r=0.69)$. As the hardness and degree of vitreousness of durum wheat kernels are related to the protein composition of the kernels (Stenvert \& Kingswood, 1977; Dexter et al., 1989), these observations were to be expected.

Assessment of the relationships between dough and pasta-handling characteristics and pasta quality illustrate that the viscoelastic nature of the semolina dough is of great importance. Thus, higher extensibility readings were associated with increased pasta firmness and optimum-cooking time (Table 5). The resistance to extensibility may also be a useful parameter to determine in relation to cooking quality, with negative correlations being observed between dough resistance and optimum-cooking time $(r=-0.64)$ and pasta firmness $(r=-0.43)$. These correlations are likely to be due to the contribution of gluten to the behaviour of the semolina doughs.

The mechanical strength of the dried spaghetti (force in Table 5) was not correlated to the textural analysis of cooked pasta. Dried pasta strength was poorly correlated to optimum-cooking time $(r=0.24)$ and pasta firmness $(r=0.38)$, whilst being negatively correlated to dough resistance $(r=-0.59), 1000$ kernel weight $(r=-0.85)$ and falling number $(r=-0.47)$. The lack of significant correlation between the mechanical strength of the dried pasta and the subsequent cooking properties is an unexpected finding, but may be related to either the low protein content of the semolina or the drying conditions of the pasta samples. Previous research has demonstrated that high-drying temperature have a positive effect on the spaghetti quality, by increasing the firmness, and decreasing the stickiness and cooking loss (Matsuo et al., 1982; D'Egidio et al., 1990; Grant et al., 1993; Malcolmson et al., 1993; Novaro et al., 1993). Thus, a relationship was expected to have occurred between the pasta-drying temperature and quality.
Results from Table 5 also indicate the possible use of the RVA as a method to analyse the durum wheat kernel quality. The final viscosity of pastes from durum wheat flours showed positive correlations for amount of semolina recovered $(r=0.53)$, the amount of protein in the semolina $(r=0.62)$, the amount of semolina gluten (wet, $r=0.51$; dry, $r=0.57$ ), the degree of kernel vitreousness $(r=0.68)$, optimum-cooking time of pasta $(r=0.51)$ and pasta firmness $(r=0.73)$. The RVA measures the pasting interactions between starch and protein in a high moisture environment and as such would be expected to be correlated to the hydration properties of the semolina, and stability of the resulting product.

\section{Conclusion}

The results of this paper indicate that some physicochemical characteristics of durum wheat genotypes were more clearly related to durum wheat milling potential, pasta processing and end-product quality than others. Protein content, kernel hardness and the degree of vitreousness were all positively correlated to semolina recovery after milling.

Additionally, durum wheat protein (gluten) content, kernel hardness and also the degree of vitreousness were important in relation to the optimum-cooking time of the pasta and the firmness of the pasta produced. These relationships are likely to be associated with the tenacity of protein binding and the formation of a strong viscoelastic protein matrix during dough formation. Such associations will provide useful traits for future developments in the Syrian durum wheat breeding programme.

The use of various assessment equipment illustrates that both extensograph and farinograph analysis can be used to evaluate the water absorption behaviour of semolina dough and hence the cooking time and firmness of pasta. However, results of the peak and final viscosity determination of durum wheat flour indicate that the RVA could be a useful tool in relating the kernel and semolina composition to potential pasta quality of durum wheat cultivars.

\section{References}

American Association of Cereal Chemists (2000). Approved Methods of the AACC, 10th edn. Methods 26-42, 54-10, 54-21, 14-22, 66-41, 66-50. St Paul, MN: American Association of Cereal Chemists.

Ames, N.P., Clarke, J.M., Marchylo, B.A., Dexter, J.E. \& Woods, S.M. (1999). Effect of environment and genotype on durum wheat gluten strength and pasta viscoelasticity. Cereal Chemistry, 76, 582586.

Autran, J.C. \& Galterio, G. (1989). Association between electrophoretic composition of protein, quality characteristics, and agronomic attributes of durum wheat. II. Protein quality associations. Journal of Cereal Science, 9, 195-215. 
Barmore, M.A. \& Bequette, R.K. (1965). Weight per bushel and flour yield of Pacific Northwest white wheat. Cereal Science Today, 10, 72-77.

Cubadda, R. (1988). Evaluation of durum wheat, semolina and pasta in Europe. In: Durum Wheat: Chemistry and Technology (edited by G. Fabriani \& C. Lintus). pp. 217-228. St. Paul, Minnesota, USA: AACC.

Cubadda, R. (1989). Current research and future needs in durum wheat chemistry and technology. Cereal Foods World, 34, 206-209.

D'Egidio, M.G., Mariani, B.M., Nardi, S., Novaro, P. \& Cubadda, R. (1990). Chemical and technological variables and their relationships: a predictive equation for pasta cooking quality. Cereal Chemistry, 67, 275-281.

Dexter, J.E. \& Matsuo, R.R. (1977). Influence of protein content on some durum wheat quality parameters. Canadian Journal of Plant Science, 57, 717-727.

Dexter, J.E. \& Matsuo, R.R. (1978a). Effect of semolina extraction rate on semolina characteristics and spaghetti quality. Cereal Chemistry, 58, 841-852.

Dexter, J.E. \& Matsuo, R.R. (1978b). The effect of gluten protein fractions on pasta dough rheology and spaghetti-making quality. Cereal Chemistry, 55, 44.

Dexter, J.E. \& Matsuo, R.R. (1980). Relationship between durum wheat proteins properties and pasta dough rheology and spaghetti cooking quality. Journal of Agriculture and Food Chemistry, 28, 899-902.

Dexter, J.E., Matsuo, R.R. \& Morgan, B.C. (1983). Spaghetti stickiness: some factors influencing stickiness and relationship to other cooking quality characteristics. Journal of Food Science, $\mathbf{4 8 ,}$ $1545-1559$.

Dexter, J.E., Matsuo, R.R. \& Martin, D.G. (1987). The relationship on durum wheat test weight to milling performance and spaghetti quality. Cereal Foods World, 32, 772-777.

Dexter, J.E., Marchylo, B.A., MacGregor, A.W. \& Tkachuk, R. (1989). The structure and protein composition of vitreous piebald and starchy durum wheat kernels. Journal of Cereal Science, 10, 1932 .

Dexter, J.E., Martin, D.G., Sadaranganey, G.T. et al. (1994). Preprocessing: effects on durum wheat milling and spaghetti-making quality. Cereal Chemistry, 71, 10-16.

Dick, J.W., Walsh, D.E. \& Gilles, K.A. (1974). The effect of field sprouting on the quality of durum wheat. Cereal Chemistry, 51, 180188.

Edwards, N.M., Mulvaney, S.J., Scanlon, M.G. \& Dexter, E.J. (2003). Role of gluten and its components in determining durum semolina dough viscoelastic properties. Cereal Chemistry, 80, 755-763.

El-Khayat, H.G., Samaan, J. \& Brennan, S.C. (2003). Evaluation of vitreous and starchy Syrian durum (Triticum durum) wheat grains: the effect of amylose content on starch characteristics and flour pasting properties. Starch, 55, 358-365.

El-Khayat, H.G., Samaan, J., Manthey, F.A., Fuller, M.P. \& Brennan, C.S. (2006). Durum wheat quality: I. Correlations between physical and chemical characteristics of Syrian durum wheat cultivars. International Journal of Food Science and Technology, 41, (Supplement 2), 110-117.

Grant, L.A., Dick, J.W. \& Shelton, D.R. (1993). Effects of drying temperature, starch damage, sprouting, and additives on spaghetti quality characteristics. Cereal Chemistry, 70, 676-684.

Greenwell, P. \& Schofield, J.D. (1986). A starch granule protein associated with endosperm softness in wheat. Cereal Chemistry, 63, 379-380.

Grzybowski, R.A. \& Donnelly, B.J. (1979). Cooking properties of spaghetti: factors affecting cooking quality. Journal of Agriculture and Food Chemistry, 27, 380-384.

Gupta, R.P., Singh, N.K. \& Shepherd, K.W. (1989). The cumulative effect of allelic variation in LMW and HMW glutenin subunits on physical dough properties in progeny of two bread wheats. Theoretical and Applied Genetics, 77, 57-64.
Gupta, R.P., Batey, I.L. \& MacRitchie, F. (1992). Relationships between protein composition and functional properties of wheat flour. Cereal Chemistry, 69, 125-131.

Hook, S.C.W. (1984). Specific weight and wheat quality. Journal of the Science of Food and Agriculture, 35, 1136-1141.

Jane, J., Chen, Y.Y., Lee, L.F. et al. (1999). Effects of amylopectin branch chain length and amylose content on the gelatinization and pasting properties of starch. Cereal Chemistry, 76, 629-637.

Johnson, R.M. \& Hartsing, T.F. (1963). Kernel count as a measure of flour milling yield. Northwestern Miller, 269, 22.

Khan, K., Figueroa, J. \& Chakraborty, K. (1990). Relationship of gluten protein composition to breadmaking quality of HRS wheat grown in North Dakota. In: Gluten Proteins (edited by W. Bushuk, \& R. Tkachuk). pp. 81-97. St Paul, Minnesota, USA: AACC.

Kovacs, M., Noll, J.S., Dahlke, G. \& Leisle, D. (1995). Pasta viscoelasticity: its usefulness in the Canadian durum wheat breeding program. Journal of Cereal Science, 22, 115-121.

MacRitchie, F. (1984). Baking quality of wheat flours. Advances in Food Research, 29, 201-277.

Malcolmson, L.J., Matsuo, R.R. \& Balshaw, R. (1993). Effects of drying temperature and farina blending of spaghetti quality using response surface methodology. Cereal Chemistry, 70, 1-7.

Mangels, C.E. (1960). Studies on TW and flour yielding capacity of wheats. Cereal Science Today, 5, 71 .

Manthey, F.A. \& Schorno, A.L. (2002). Physical and cooking quality of spaghetti made from whole wheat durum. Cereal Chemistry, 79, 504-510.

Martinez, M.D, Ruiz, M \& Carrillo, J.M. (2004). New B low M-r glutenin subunit alleles at the Glu-A3, Glu-B2 and Glu-B3 loci and their relationship with gluten strength in durum wheat. Journal of Cereal Science, 40, 101-107.

Matsuo, R.R. \& Dexter, J.E. (1980). Relationship between some durum wheat characteristics and semolina milling properties. Canadian Journal of Plant Science, 60, 49-53.

Matsuo, R.R., Bradley, J.W. \& Irvine, G.N. (1972). Effect of protein content on the cooking quality of spaghetti. Cereal Chemistry, 49, $707-711$.

Matsuo, R.R., Dexter, J.E., Kosmolak, F.G. \& Leisle, D. (1982). Statistical evaluation of tests for assessing spaghetti-making quality of durum wheat. Cereal Chemistry, 59, 222-228.

Miller, B.S., Afework, S., Pomeranz, Y., Bruinsma, B.L. \& Booth, G.D. (1982). Measuring the hardness of wheat. Cereal Food World, 27, 61-64.

Mousa, I.E., Shuey, W.C., Manveval, R.D. \& Banasik, O.J. (1983). Farina and semolina for pasta production. I. Influence of wheat classes and granular mill steams on pasta quality. Operative Millers Technical Bulletin, July, 4083-4087.

Novaro, P., D'Egidio, M.G., Mariani, B.M. \& Nardi, S. (1993). Combined effect of protein content and high temperature drying systems on pasta cooking quality. Journal of Cereal Science, 70, 716719.

Payne, P.I. (1987). Genetics of wheat storage proteins and the effect of allelic variation on bread-making quality. Plant Physiology, 38, 141

Pomeranz, Y. (1987). Grain quality. In: Modern Cereal Science (edited by Y. Pomeranz). pp. 72-149. New York: VCH Publishers

Posner, E.S. \& Hibbs, A.N. (1997). Wheat Flour Milling. St. Paul, MN, USA: AACC.

Sharma, R., Sissons, M.J., Rathjen, A.J. \& Jenner, C.F. (2002). The null-4A allele at the waxy locus in durum wheat affects pasta cooking quality. Journal of Cereal Science, 35, 287-297.

Shewry, P.R. \& Miflin, B.J. (1985). Seed storage proteins of economically important cereals. In: Advances in Cereal Science and Technology (edited by Y. Pomeranz). pp. 1-83. St Paul, Minnesota, USA: AACC.

Shuey, W.C. (1960). A wheat sizing technique for predicting flour milling yield. Cereal Science Today, 5, 71 . 
Shuey, W.C. \& Gilles, K.A. (1972). Milling evaluation of hard red spring wheats. III. Relation of some physical characteristics to milling. Northwestern Miller, 279, 14.

Stenvert, N.L. \& Kingswood, K. (1977). The influence of the physical structure of the protein matrix on wheat hardness. Journal of the Science of Food and Agriculture, 28, 11-19.

Troccoli, A., Borreli, G.M., De Vita, P., Fares, C. \& Di Fanzo, N. (2000). Durum wheat quality: a multidisciplinary concept. Journal of Cereal Science, 32, 99-113.

Tudorica, C.M., Kuri, V. \& Brennan, C.S. (2002). Nutritional and physiochemical characteristics of dietary fiber enriched pasta. Journal of Agriculture and Food Chemistry, 50, 347-356.

Walsh, D.E., Ebeling, K.A. \& Dick, J.W. (1971). A linear programming approach to spaghetti processing. Cereal Science Today, 16, 385
Watson, C.A., Sibbitt, L.D. \& Banasik, O.J. (1977a). Relation of grading and wheat quality factors to end-use quality characteristics for hard red spring wheat. Baker's Digest, 51, 38.

Watson, C.A., Banasik, O.J. \& Sibbitt, L.D. (1977b). Relation of grading and wheat quality factors to end-use quality characteristics for durum wheat. Macaroni Journal, 58, 10

Weegels, P.L., Hamer, R.J. \& Schofield, J.D. (1996). Critical review. Functional properties of wheat glutenin. Journal of Cereal Science, 23, $1-18$.

Wrigley, C.W. \& Bietz, J.A. (1988). Proteins and amino acids. In: Wheat Chemistry and Technology, 3rd edn (edited by Y. Pomeranz). pp. 159-275. St Paul, Minnesota, USA: AACC.

Zeng, M., Morris, F.C., Batey, L.I. \& Wrigley, W.C. (1997). Sources of variation for starch gelatinization, pasting and gelation properties in wheat. Cereal Chemistry, 74, 63-71. 